\title{
Business-catalysts as Drivers of Regional Innovation Systems
}

\author{
Sergey Makarov, Ekaterina Ugnich
}

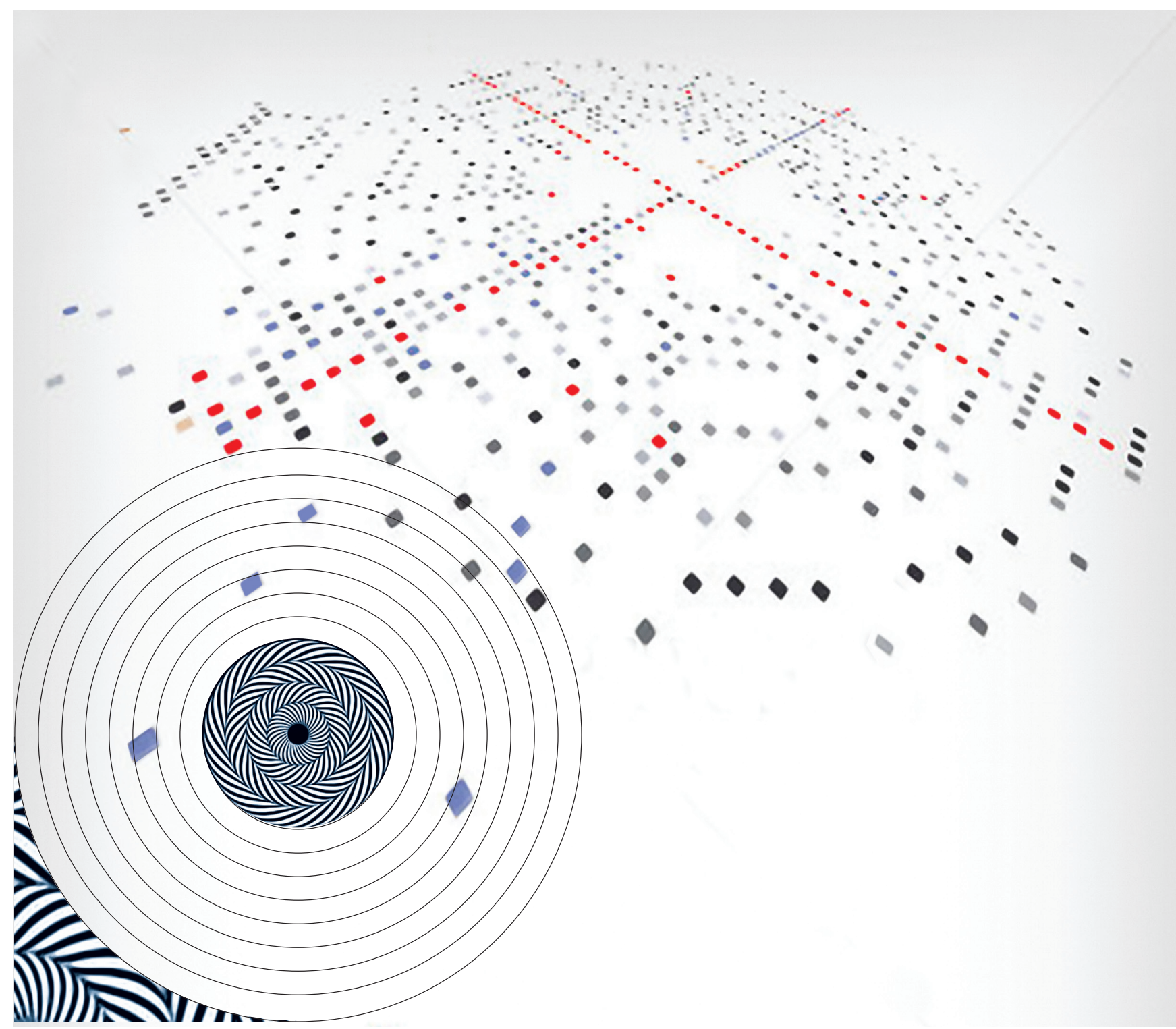

The task of building of an innovative economy requires mechanisms and institutions that will ensure the continuity of innovative process and contribute to the successful commercialization of innovations. Foreign experience of recent years has shown the importance of the accelerating mechanism of innovative project support on the principles of which the activity of the regional business-catalyst is built. The prospects for regional business-catalysts are seen in the development of their network interaction as an important element of an open business entrepreneurial culture and the expansion of partnership relations in the region with the industrial and scientific community.
Sergey Makarov - Investment Manager, Russian Venture Company. Address: 29 Serebryanicheskaya nab., Moscow 109028, Russian Federation.E-mail: s.e.makarov@gmail.com

Ekaterina Ugnich - Associate Professor, Don State Technical University. Address: 1 Gagarina sq., Rostov-on-Don 344010, Russian Federation. E-mail: ugnich77@mail.ru

\section{Keywords}

accelerator; regional business-catalyst; innovative process; 'the valley of death'; innovation infrastructure

DOI: $10.17323 / 1995-459 X .2015 .1 .56 .67$ 
$\mathrm{T}$ The position of a national economy in the modern global economy is determined by the quality and depth of its links between science, innovation and economic growth. In Russia, this growth is predominantly based on resource and raw material potential and does not show any signs of reorientation towards innovation, a fact corroborated by empirical observations. In 2011, less than $1 \%$ of spending by domestic companies went on the acquisition of new technologies; meanwhile, the procurement of patents, licences and other innovation activity work accounted for only $0.2 \%$. Statistics demonstrate the low percentage of organizations involved in technological, organizational and marketing innovations: $10.1 \%$ in $2013 .{ }^{1}$ Based on this figure, which is characteristic of the level of innovation activity in the country, the Russian economy is falling behind not only leading industrial nations (Germany - 70\%, Canada - 65\%, Belgium - 60\%, Ireland, Denmark and Finland - 55-57\%), but also the majority of countries in Central and Eastern Europe, where this figure lies between 20\% and 40\% [Gokhberg, Kuznetsova, 2011; HSE, 2011, p. 10].

One way to overcome this weakness could be to create conditions that are conducive for enterprises to independently use their resources more efficiently by capitalizing on the results of scientific research and development $(\mathrm{R} \& \mathrm{D})$. This task is largely dependent on the existence of an advanced innovation infrastructure, which allows for a variety of forms of resource and information exchange between economic actors and contributes to the success of innovative enterprises, especially in the early stages of development. At present, Russia has not elaborated any clear mechanisms for infrastructure institutions to collaborate with innovative companies, and the role of key elements of this infrastructure has not yet been agreed upon. Existing contradictions between certain segments of the innovative ecosystem reduce the efficiency of support mechanisms for innovative enterprises, especially new businesses.

The task of building an innovation-oriented economy that is capable of responding to a country's challenges and threats comes up against many problems. Solving these problems very much depends on the theoretical understanding of the conditions and support mechanisms for innovative companies. The problem of developing and operating an innovation infrastructure and its component elements is addressed in numerous works by foreign and Russian academics [for example, Etzkowitz, 2003; Etzkowitz, Pique, 2005; Malek et al., 2012, 2014; Ammosov, 2005; Golichenko, 2006; Gokhberg, 2003; Gokhberg, Kuznetsova, 2009; Gokhberg et al., 2013]. Despite the clear interest in this problem, many issues have still not been addressed in sufficient depth, in particular the mechanisms used to establish infrastructural support for start-up innovation companies. Foreign experience in recent years has shown the effectiveness of an accelerated support mechanism in the form of business catalysts.

This article focuses on substantiating the role and place of a regional business catalyst in the system of innovation infrastructure instruments and institutions. The article assumes that regional business catalysts are the most optimal mechanism to search for and support promising innovative companies and projects.

To describe real economic processes, the study used a situational analysis method making it possible to describe the current state of affairs, to understand existing problems and propose possible means to overcome these problems. In short, this method enabled us to study current phenomena in real conditions [Yin, 2003]. System analysis methods offered the opportu- 
nity to identify the core characteristics of the innovation infrastructure instruments and institutions in a changing economic environment. The study was also based on evolutionary economics principles [Nelson, Winter, 1982] which stress that further development is only maintained and achieved by institutions that have the largest set of favourable properties and aid the successful development of the economy and society.

Innovation infrastructure includes innovative technology centres, technology parks, special economic zones, common use centres, development funds and other specialist institutions. The authors of this article have focused on non-financial means of support for innovative companies in their early stages of development, when they are experiencing the greatest difficulties in searching for resources and establishing the necessary conditions to carry out their projects.

\section{The development of regional innovation infrastructure: Negotiating the 'valley of death'}

Building an innovation-oriented economy is not only linked to adapting to pressing global economic trends, but also to searching for and capitalizing on a country's strategic advantages worldwide. The regional diversity of the Russian economy presents unique opportunities to achieve this goal. However, the imbalances between some regions in their levels of social and economic development and the large differences in resource potential between regions mean that innovative development mechanisms and institutions need to be created. These mechanisms and institutions would help to create a synergetic effect in the context of an overarching, country-wide strategy to build an innovative economy. Overcoming such contradictions is only possible through creating the institutional conditions to stimulate and energize the innovative process. The lack of effective mechanisms to set this in motion and support it on a regional level prevents the modernization of the country's economy as a whole.

Not all Russian federal regions with significant science and technology potential have achieved a high level of innovative development. The share of innovative output in their gross regional product is of ten small and the prospects of raising this share are unclear. Low innovation activity in such cases, as a general rule, is caused not by a lack of interesting projects, but rather cautiousness on the part of investors and the strict criteria they impose on the quality of the administrative teams, mechanisms and instruments and the weaknesses of the existing industrial base.

The stages of the innovation cycle from the conception of an idea to the launch of a product on a market are characterized by a gradual fall in investment risks and growth in potential investor income [Ammosov, 2005]. Each of these stages calls for the development of an individual mechanism to dampen risks and to raise funds. The early stages of the innovation cycle - the seed stage - pose the greatest threat to a new enterprise. The seed stage involves the emergence of ideas and initial results from $R \& D$, but without any income or the legal registration of the enterprise. The investment appeal of such projects is based on how well developed the business plan is. Start-ups, which, as a rule, already have developmental prototypes and legal registration, are trying to push their product onto the market and are carrying out market research. It is at these stages, when passing the socalled 'valley of death', that innovative companies are in particular need not only of access to funding sources, but also of support for the future innovative product in the form of experience and knowledge in market and patent analysis, management and business model building skills. The difficulties experienced by companies negotiating the 'valley of death' are aggravated 
in Russia by the operational characteristics of the innovation environment, namely the lack of a clear understanding of the make-up and boundaries of innovation activity, poor links between those engaging in such activity and the lack of information transparency [Gokhberg et al., 2013]. Russian enterprises are guilty of inertia in the development of collaborative links and searching for and making use of information linked to their activities and markets; many of them are locked in on their own potential and do not show any interest in intensive technology exchanges [Gokhberg, Kuznetsova, 2009]. Eliminating this problem is largely dependent on the effectiveness of the innovation infrastructure, including certain financial organizations and production, technological, consulting and other component elements [Etzkowitz, 2003; Etzkowitz, Pique, 2005; Hoffman, Radojevich-Kelley, 2012; Malek et al., 2012, 2014; and others].

Access to investment resources is directly shaped by the quality of the innovation project: its degree of originality, potential market demand, the clarity and detail of the business plan, and the existence of a team capable of realizing the project. A poor understanding of business development mechanisms does not of ten allow for the required quality of the new project to be guaranteed on the part of the initiator. Innovation infrastructure instruments such as business incubators and business accelerators are widely recognized to make a project more attractive in an investor's eyes by improving all these components. In the early stages of a company's development, the so-called 'growth principle' is key, meaning the creation of the most favourable conditions to support its growth.

Effective, flexible innovation support forms and instruments could and should be used not only centrally across the whole country but also regionally [Etzkowitz, Pique, 2005]. This means instruments that allow innovative companies to access the organizational, scientific, research, technical and technological skills that, being concentrated in a single level of control, facilitate the effective transition through the most risky stages of the innovative cycle. The involvement of those with such skills raises the quality of the innovation projects and makes it possible to reduce expenditure on pre-seed investment.

\section{An innovation project acceleration mechanism: origins and development}

The evolution of methods and means to control economic processes gave rise to special instruments that help newly starting companies negotiate the 'valley of death' by providing them with the necessary resources, creating specific conditions and offering services. These instruments transform and improve under the influence of the ever-changing needs of those involved in innovation activity and the new challenges facing them. As the number of players on the innovation market expands, so too do the demands about the level of access to innovation infrastructure. One of the most effective elements of this could be business incubators.

The first business incubator, Batavia Industrial Centre, was formed in 1959 in the industrial centre of the state of New York, USA, as a source of new workplaces [Lewis et al., 2011]. Its purpose was to provide newly created innovative enterprises with consultancy, accounting, legal and other services, and to provide them with premises upon which to operate. This allowed new players in the innovation sphere to reduce the costs of breaking onto the market by making it easier to access resources and to increase their business motivation [Abetti, 2004].

Another instrument is a business accelerator, which is in many ways based on similar principles to the business incubator model, yet is geared towards 
more intensive development of 'start-up' innovation projects over a shorter time frame. In the 1980s and 1990s, business incubators and business accelerators were viewed more as scientific laboratories than as institutions providing seed funding [O'Connell, 2011]. However, in the early 2000s, following the internet revolution and the so-called dot-com boom, many startup enterprises lacked access to the capital market. This served as an incentive for the appearance of a new type of accelerators under the guidance of experienced, successful entrepreneurs offering support to companies in various forms and showing a willingness to offer them seed funding.

Business accelerators are different from other innovation infrastructure instruments in five main ways [Malek et al., 2014]. First, there is competitive selection of enterprise projects and teams. Many of those submitting applications to join an accelerator are students in their final years at university. These applications are competitive and attractive to investors in terms of labour costs. Second, business accelerators support a wider range of innovation projects compared to business incubators. Third, an 'exchange' of resources and services to start-up enterprises occurs for access to a holding interest in their capital. Fourth, the projects in business accelerators grow at a relatively high speed and intensity: the duration of accelerated programmes ranges from three (for media and internet companies) to six months. Finally, a spirit of free cooperation and mutual support exist among teams of accelerator participants. Accelerators are often set up on the back of venture capital funds, business incubators or technology parks. Aside from start-up capital, innovation projects form added value through intensive mentoring and social network engagement [Hoffman, Radojevich-Kelley, 2012].

Accelerators are a union of experienced businessmen who provide guidance, mentoring, networking, project management, offer office services, and share their knowledge and experience with start-up company employees, helping them to overcome the difficulties surrounding the early stages of the life cycle. Accelerators see the uncertainty of the economic environment as favourable conditions for investment in innovation, especially in technology, as during this time costs reduce and opportunities for new developments tend to open up. As such, accelerators are an innovation infrastructure institution, which provides support to companies in their early stages of development. They can be seen as one of the mechanisms to increase company growth rates in a turbulent economic environment. The unique feature of this instrument lies in the depth of the technological and business expertise provided to participants. In essence, it is a commercial model for receiving quick investment with the assistance of an effective development institution supported both by the state and universities.

The first accelerator that aimed to launch innovative projects is considered to be the Y-Combinator, which was set up in California in 2005 [Miller, Bound, 2011]. In recent years, the number of business accelerators in the USA has risen considerably, which confirms the popularity and effectiveness of this instrument. A similar situation was seen in Europe: the first accelerator, Seedcamp was set up in London in 2007 and has now gained pan-European status, receiving more than 2,000 applications per year [Butcher, 2011]. Since its creation, Seedcamp has 'released' 110 innovation companies, which have attracted investment totalling 65 million US dollars.

Globally, there are more than 700 accelerators. The most successful of them are considered the American Y-Combinator and TechStars, which have already helped 566 and 248 innovative companies, respectively, to reach the market. The survival rate of projects after growing in these accelerators is more than 85\%. In Russia, business accelerators started to appear in 2009. Today, 326 innovation projects are developing in 27 Russian accelerators. 
However, over the period 2011-2013, only eight of these projects managed to attract investment. In the majority of cases, Russian investment management organizations (Glavstart, Plug and Play, Pulsar Venture, Techno Cup and others) are geared towards supporting information and communication technologies (ICT) and developments in various scientific fields and industrial sectors [RVC, 2014].

The popularity of this support instrument for innovation projects in their early stages is down to the specific nature of the business strategy, which guarantees links between scientific developments, industrial production, and services to push through and commercialize projects [Miller, Bound, 2011]. The main advantage is the shorter time frame for innovative products to reach the market through the opportunities to carry out the necessary $R \& D$, reduce administrative costs, and search for investors more quickly. At the same time, the technological and operational risks of projects are reduced [Malek et al., 2012], and their chances of being successfully commercialized are increased.

However, experts have pointed out certain problems which could reduce the effectiveness of this instrument. The length of the acceleration cycle ranges from only 3 to 6 months, meaning that a relatively young enterprise is launched onto the market when it cannot always fend for itself in a competitive environment. In addition, participating companies provide accelerators with relatively little information at the selection stage, which of ten does not allow them to adequately assess their potential. Moreover, support in the early stages to some extent strips a business of its 'entrepreneurial spirit' and competitive skills. As a result, such players are less attractive to investors, which are geared towards the strict market mechanisms that more reliably shape the prospects of new companies. Ultimately, it is the approach itself that is disputed, as it is based on many relatively fortuitous investments in the hope of making it in a particular industry. Experts consider a small number of targeted investments to be more effective [Miller, Bound, 2011].

The emergence of accelerators was, to a certain degree, a reaction to the shortcomings of the university education system in terms of instilling and spreading the required practical entrepreneurial (innovation) skills. A shorter and more intensive training cycle coupled with real business experience increases the appeal of accelerators in the eyes of students and young entrepreneurs. Overcoming these pitfalls is hardly possible without state involvement.

The activities of business accelerators are associated with certain operational costs - leasing premises, bringing in experts, promoting projects, etc. According to data from the World Bank, these costs can vary from 2,000 to 115,000 US dollars [World Bank, infoDev Finance, 2012]. Coupled with the problems of searching for successful business models amid an uncertain market climate and an unstable institutional environment in Russia, this makes the activities of business accelerators more difficult with private capital. At the same time, business catalysts have started to spring up with the involvement of state and development institutions, also based on the accelerator principle.

\section{A regional business catalyst model: opportunities and limitations}

A regional business catalyst is an instrument to generate and select the most promising completed $\mathrm{R} \& \mathrm{D}$ projects and quickly roll them out on the market by developing the acceleration principle outlined above. One of its main aims is to increase the number of innovation projects and ensure that they are 'investment quality'. 
A business catalyst brings together innovation process participants in a region to establish and support innovation projects in their early stages, when even the very idea of a new business is still in need of endorsement. It is based on amalgamating the skills of key innovation system players in a region - universities, research organizations, industrial enterprises, financial institutions, private investors, regional authorities - with the entrepreneurial resources of the project initiator. The involvement of all of these parties makes it possible to reduce initial investment costs i.e. to solve the most pressing problem of any new project which is accessing resources. A local business catalyst provides developers and entrepreneurs - both residents and non-residents in a region - with a range of services to bring an innovation project to the stage of investment readiness in exchange for a share, for example, in the emerging company or a company participating in a regional business catalyst. Common standards and a transparent project selection procedure make this mechanism effective.

Therefore, a regional business catalyst makes it possible to negotiate the 'valley of death' and energize innovation activity in a region with the help of a mechanism to prepare innovative companies for investment by synchronizing and coordinating the skills of its participants. The main elements of a regional business catalyst model are set out below (Figure 1).

An innovation project 'growth' programme at a regional business catalyst tends to last on average three months and is made up of six stages:

1. Entry into a project: searching for ideas and developments. Ideas to be considered in a business catalyst can be presented by participants and external partner structures - business incubators, enterprises and individual entrepreneurs in a region;

2. Expert assessment and project screening is based on criteria such as the level of novelty, competitiveness, practical feasibility, commodification opportunities (transformation into a commodity), and prospects of protecting intellectual property rights;

\section{Figure 1. A regional business catalyst model}

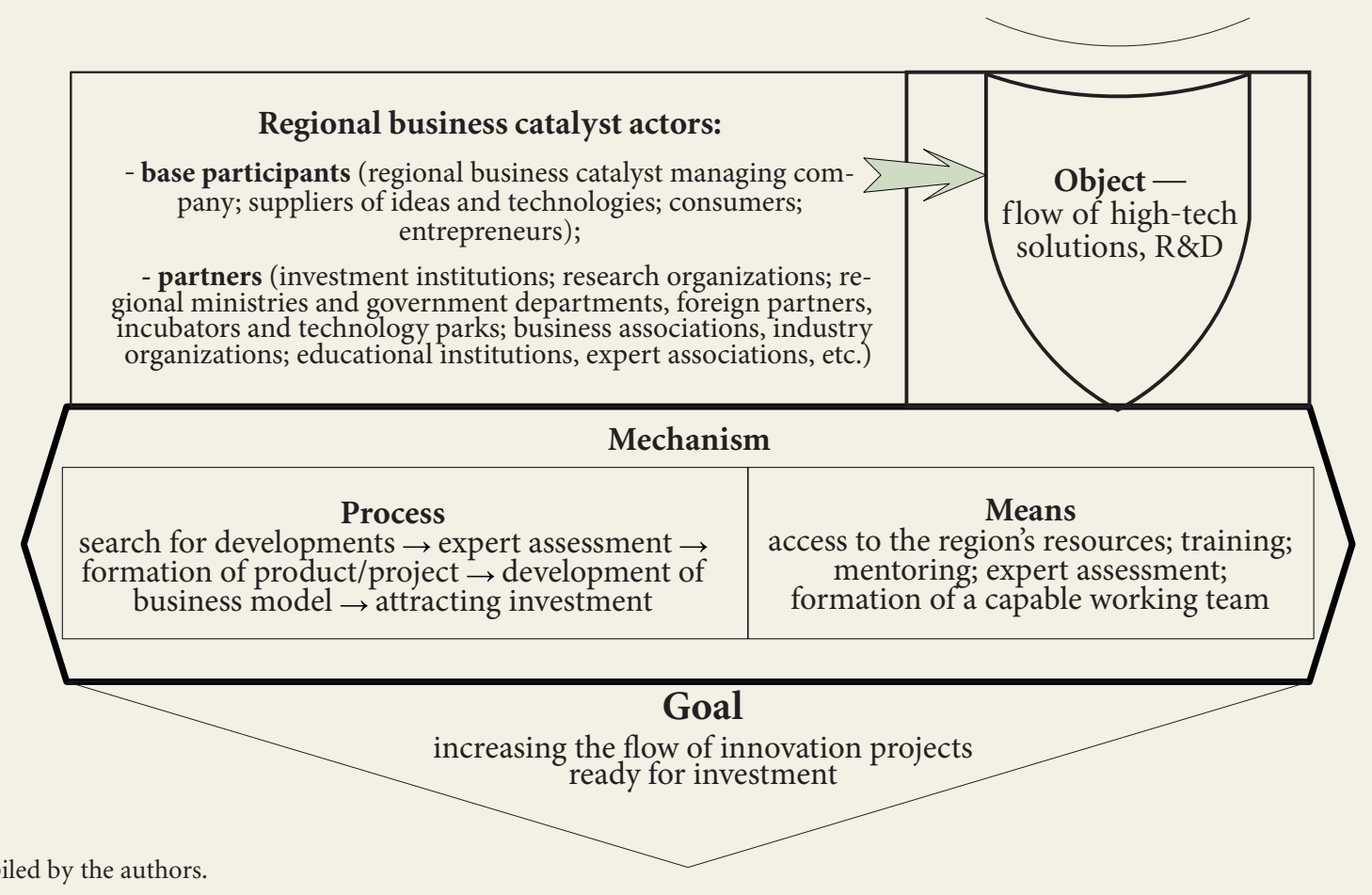


3. Launch of design work, product creation. Upon completion of this phase, a clear concept of the product is formed, receiving its first reactions from the market and potential customers;

4. Business modelling involves an assessment of the team's ability to complete the project, carry out market research, analyse consumer values, product distribution channels, and incomes and expenditure, analyse the rate of return, identify key partners and the necessary resources, and hone down the company's development plan;

5. Company creation and search for an investor. The role of a business catalyst at this stage involves assisting in registering intellectual property rights to a development, creating a legal entity, organizing staff and accounts, and selecting investors that match the required profile;

6. Leaving the project. Attracting seed funds (an investor) and selling a share in the company.

Upon the completion of each stage, projects are screened to remove any that do not meet the stipulated criteria and conditions. According to our assessments, out of the 200 ideas and developments at the entry stage prior to assessment by an expert committee in a regional business catalyst, only roughly 40 projects will make it through. Of these, 8-12 will likely reach the stage of direct developmental work in the business catalyst, and only 4-8 of these prepared investment applications will reach the end point. The more general outcome of regional business catalysts' activity is stimulating entrepreneurial initiatives, creating business prospects that are attractive to investment and, as a result, increasing the innovation activity and potential of a region.

A regional business catalyst differs from a business accelerator in three main ways. First, it is aimed at bringing together the skills of those involved in innovation activity in a particular region with the skills of mentors from the business community who have experience in speeding up (accelerating) the early stages of the innovation cycle. Second, in a business catalyst innovative ideas are transformed into projects ready for investment. Third, a bootstrapping mechanism lies at its foundation, meaning that existing resources are used as efficiently as possible, including non-fiscal incentives at the pre-seed project development stage.

The innovation infrastructure instruments examined in Table 1 may be interlinked, complementary, and constitute a single innovation project sup-

\begin{tabular}{|c|c|c|c|}
\hline & Business incubator & Business accelerator & Business catalyst \\
\hline Aim & $\begin{array}{l}\text { To stimulate accelerated } \\
\text { development of newly started } \\
\text { innovation companies }\end{array}$ & $\begin{array}{l}\text { To create quality innovation } \\
\text { projects for investment }\end{array}$ & $\begin{array}{l}\text { To generate and increase the number } \\
\text { of innovation projects in a region for } \\
\text { investment }\end{array}$ \\
\hline $\begin{array}{l}\text { Basic principles } \\
\text { of support }\end{array}$ & $\begin{array}{l}\text { To create favourable } \\
\text { conditions, to provide the } \\
\text { necessary resources and } \\
\text { services }\end{array}$ & $\begin{array}{l}\text { To intensively develop } \\
\text { innovation projects by } \\
\text { guaranteeing access to the } \\
\text { necessary resources and skills }\end{array}$ & $\begin{array}{l}\text { To expedite the creation and } \\
\text { development of innovative projects } \\
\text { by granting access to the necessary } \\
\text { resources and training in the necessary } \\
\text { skills for residents }\end{array}$ \\
\hline Main initiators & $\begin{array}{l}\text { Higher education institutions, } \\
\text { research institutions, large } \\
\text { companies, the state }\end{array}$ & $\begin{array}{l}\text { Investment funds, business } \\
\text { incubators, entrepreneurs, the } \\
\text { state }\end{array}$ & $\begin{array}{l}\text { Universities, research institutions, } \\
\text { business incubators, development } \\
\text { institutes }\end{array}$ \\
\hline $\begin{array}{l}\text { Developmental level } \\
\text { of projects (companies) } \\
\text { drawn in }\end{array}$ & As a rule, start-ups & Seed stage & Pre-seed and seed stages \\
\hline 'Growth' term & Up to 3 years & 3-6 months & 3-4 months \\
\hline
\end{tabular}


port system. Thus, for example, in the region of Astrakhan, the business catalyst was set up on the basis of the LIFT business incubator [Timokhina, 2014], while Moscow State University set up its own accelerator in its business incubator [Akkerman, 2014].

A business catalyst helps to increase the number of transactions taking place in a region to provide seed and pre-seed funding, with all interested actors of a regional innovation system involved. The regional business catalyst organizational mechanism assumes that an interested innovation infrastructure participant is registered as a legal entity. Several business catalysts in Krasnoyarsk, Rostov, Astrakhan, Kaluga, and Samara regions already operate on this basis. These regions are characterized by relatively high scientific, educational and innovation potential, a developed innovation infrastructure and an innovation support system from regional authorities. The Russian Venture Company was behind their creation with the involvement of the Moscow School of Management SKOLKOVO (Table 2).

\section{Case study: The Rostov Oblast regional business catalyst}

The business catalyst model described in the article was first launched in test form at the end of 2012 in Rostov region, based at the Don State Technical University. Of the 130 applications submitted to the regional business catalyst in 2013, six projects passed the expert selection process, received mentoring support and were later presented to investors from the Moscow School of Management SKOLKOVO business community (Figure 2). Four projects reached the stage of signing contracts with investors: one each in the energy and ICT sectors and two in the mechanical engineering sector.

The Rostov regional business catalyst has a diversified portfolio of projects in different industries: 33\% fall under mechanical engineering and 26\% re-

\section{Table 2. Characteristics of regional business catalysts in the Russian Federation}

\begin{tabular}{|c|c|c|c|c|c|}
\hline $\begin{array}{l}\text { Launch location of } \\
\text { regional business } \\
\text { catalysts }\end{array}$ & Kaluga Oblast & Astrakhan Oblast & Krasnoyarsk Krai & Samara Oblast & Rostov Oblast \\
\hline $\begin{array}{l}\text { Year of launch } \\
\text { (in test form) }\end{array}$ & 2013 & 2013 & 2013 & 2014 & $\begin{array}{l}2012 \\
\text { Since } 2013 \text { it has been } \\
\text { operating in full in the } \\
\text { form of a ZAO Regional } \\
\text { Business Catalyst }\end{array}$ \\
\hline $\begin{array}{l}\text { Support from } \\
\text { regional } \\
\text { authorities }\end{array}$ & $\begin{array}{l}\text { Ministry of } \\
\text { Economic } \\
\text { Development of } \\
\text { Kaluga Oblast }\end{array}$ & $\begin{array}{l}\text { Ministry of } \\
\text { Economic } \\
\text { Development of } \\
\text { Astrakhan Oblast }\end{array}$ & $\begin{array}{l}\text { Ministry of } \\
\text { Investment and } \\
\text { Innovation of } \\
\text { Krasnoyarsk Krai }\end{array}$ & $\begin{array}{l}\text { Ministry of } \\
\text { Economic } \\
\text { Development, } \\
\text { Investment and } \\
\text { Trade of Samara } \\
\text { Oblast }\end{array}$ & $\begin{array}{l}\text { Ministry of Economic } \\
\text { Development of Rostov } \\
\text { Oblast and Department } \\
\text { of Investment and } \\
\text { Enterprise of Rostov } \\
\text { Oblast }\end{array}$ \\
\hline Base organization & $\begin{array}{l}\text { OAO Innovative } \\
\text { Development } \\
\text { Agency - Kaluga } \\
\text { Oblast Cluster } \\
\text { Development } \\
\text { Centre }\end{array}$ & $\begin{array}{l}\text { The private } \\
\text { technology } \\
\text { park Fabrika } \\
\text { (LIFT business } \\
\text { incubator) }\end{array}$ & $\begin{array}{l}\text { The Krai state } \\
\text { autonomous } \\
\text { institution } \\
\text { Krasnoyarsk } \\
\text { Regional Innovation } \\
\text { Technology Business } \\
\text { Incubator }\end{array}$ & $\begin{array}{l}\text { The non-profit } \\
\text { partnership Regional } \\
\text { Innovation Centre }\end{array}$ & $\begin{array}{l}\text { The federal state } \\
\text { budgetary educational } \\
\text { institution Don State } \\
\text { Technical University }\end{array}$ \\
\hline $\begin{array}{l}\text { Number of } \\
\text { projects presented } \\
\text { to investors }\end{array}$ & 1 & 5 & 5 & 3 & 6 \\
\hline $\begin{array}{l}\text { Priority 'growth' } \\
\text { project areas }\end{array}$ & $\begin{array}{l}\text { ICT; automation } \\
\text { and control; } \\
\text { energy and } \\
\text { energy saving }\end{array}$ & $\begin{array}{l}\text { ICT; agriculture } \\
\text { and agribusiness; } \\
\text { energy and energy } \\
\text { saving }\end{array}$ & $\begin{array}{l}\text { Metallurgy; ICT; } \\
\text { energy and resource } \\
\text { saving; mechanical } \\
\text { engineering }\end{array}$ & $\begin{array}{l}\text { ICT; automation and } \\
\text { control; mechanical } \\
\text { engineering }\end{array}$ & $\begin{array}{l}\text { Mechanical engineering; } \\
\text { mechatronics and } \\
\text { robotics; energy and } \\
\text { energy saving; ICT; } \\
\text { automation and control; } \\
\text { food industry; medical } \\
\text { equipment }\end{array}$ \\
\hline
\end{tabular}

Source: compiled by the authors. 
130 applications of ideas and developments

42 applications reviewed by experts

10 projects received mentoring support

6 projects signed

contracts with

investors

Source: compiled by the authors.

late to energy and energy saving (Figure 3). The dominance of projects of this profile can be explained by their attractiveness to the region's economy and the key role played by these industries in the region. $80 \%$ of all regional output comes from fuel, energy, mechanical engineering, and food industries. The main source of innovation projects for the business catalyst is scientific ideas and solutions developed by the region's universities and research organizations.

A business catalyst's activities are accompanied by difficulties caused by the specific nature of the projects' technical and scientific expert assessments and the inadequate coherence of key elements of a region's innovation ecosystem. In part, reinforcing the industry specialization of a business catalyst would make it possible to overcome these problems, thereby helping the optimization of the development of the end product and the strengthening of the innovation potential of the projects. At the same time, it is important to remember that acceleration is far from desirable for all projects. While an ICT project can be pushed through a business catalyst in three months, for biomedicine - where the development period for a new product and technology ranges from three to five years or more - the accelerated 'growth' mechanism is counter-productive. As stressed above, in an unstable institutional environment and in the absence of adequate skills, resources, information sources, and links between innovation project developers and the

Figure 3. Breakdown of projects in the Rostov regional business catalyst by economic sector $(\%)$

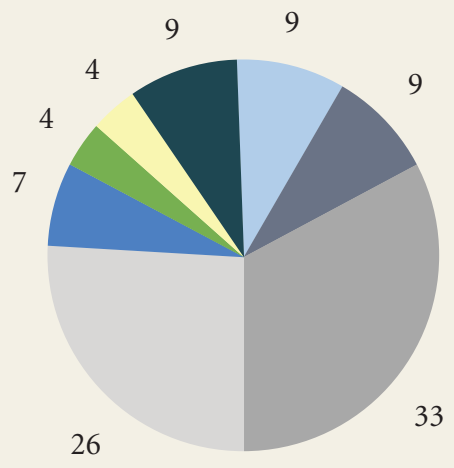

construction

- mechatronics and robotics

- mechanical engineering

$\square \quad$ energy and energy saving

- ICT, software

- automation and control

$\square$ food industry

- medical equipment 
business community, involvement in a regional business catalyst becomes essentially the only way to prepare a quality project in a short time frame which is capable of attracting investors' attention.

The prospects of further developing regional business catalysts are connected with integrating them into a network, which would facilitate collaboration, an exchange of skills and information, and the spread of best practices nationally. The question of the rationality and limits of state involvement in funding new elements of a regional innovation infrastructure is still disputed. Such involvement can be examined in a number of other innovation support instruments (innovation projects and teams) in the early stages of work. However, full budgetary funding for business catalysts risks isolating them from the investor community and risks problems arising in attracting private capital in later stages. ${ }^{2}$ The likelihood of expanding the network of regional business catalysts is also linked to the open nature of business catalysts, a transparent mechanism for providing resources, accessible information on the current status of projects, etc. Openness also presupposes a willingness among mentors to offer free consultations, and a will among innovative companies to share their business secrets with other participants. An open network of skills to establish a flow of 'investment quality' projects operating on principles such as enterprise, partnership and state support ensures - if participants keep to their responsibilities - that the business catalyst mechanism can quickly adapt to changing external environmental conditions.

\section{Conclusion}

This study confirms the potential of using regional business catalysts as an effective instrument to support start-up innovative enterprises. With the help of these business catalysts, developers and project initiators can find the best possible means to implement their projects, and investors and innovation managers can select the most effective forms of investment in innovation.

This support for the innovation process is provided in the early stages through accelerated programmes. It is based on generating, synchronizing and coordinating the skills of those involved in the innovation process, and aims to ensure a flow of commercial transactions from an uncoordinated mass of completed $\mathrm{R} \& \mathrm{D}$ projects.

An analysis of the distinguishing features of the business catalyst model compared with business incubators and business accelerators shows that a business catalyst not only brings together the skills of its participants, initiators and mentors, but also establishes common standards and a transparent selection procedure to generate innovative ideas and transform them into a project that is ready for investment. At the foundation of a regional business catalyst's work is a mechanism to make the most use of existing resources, as well as non-fiscal incentives for investment in the pre-seed project development stage.

This article discussed the history of one of the five business catalysts that currently exist in Russia, which since 2013 has prepared and presented six innovation projects spanning various economic sectors to investors in the Rostov region. This case study demonstrates not only the undisputed advantages of the business catalyst in the Rostov region for the development of innovation processes regionally (which is especially important in Russia

\footnotetext{
${ }^{2}$ It is widely recognized that the presence of the private investment component is extremely important when implementing many state policy instruments. As such, when setting up new high-tech companies, proactive efforts aimed at establishing an institutional environment are effective. Private measures (reactions to market collapse in the form of subsidies and investment in 'strategic' industries) are often counter-productive and have the opposite effect [Abetti, 2004].
} 
in view of the country's varied 'economic geography') but it also highlights the clear problems caused primarily by the inadequate links between key elements of the local innovation ecosystem.

The prospects of successful regional business catalysts rely on the formation of networked collaboration between them, as well as ensuring that such structures are open, and expanding partnerships between industry, research, and state development institutions in supporting innovative enterprises.

\section{References}

Abetti P.A. (2004) Government-Supported Incubators in the Helsinki Region, Finland: Infrastructure, Results, and Best Practices. Journal of Technology Transfer, vol. 29, pp. 19-40.

Akkerman K. (2014) QIWI vzyalas' za startapy. V Moskve proshla prezentatsiya biznes-akseleratora QIWI Universe [QIWI undertook in startups. Moscow saw a presentation of business accelerator QIWI Universe]. Bankir.Ru, 28.07.2014. Available at: http://bankir.ru/novosti/s/qiwi-vzyalas-za-startapy-10082383/, accessed 09.12.2014 (in Russian).

Ammosov Yu. (2005) Venchurnyi kapitalizm: ot istokov do sovremennosti [Venture capitalism: From the beginnings to the present], Saint-Petersburg: Feniks.

Butcher M. (2011) Seedcamp named top European accelerator, with Startupbootcamp closing in. TechCrunch, 20.06.2011. Available at: http://techcrunch.com/2011/06/20/seedcamp-named-top-european-accelerator-with-startupbootcampclosing-in/, accessed 14.02.2015.

Etzkowitz H. (2003) Innovation in Innovation: The Triple Helix of University-Industry-Government Relations. Social Science Information, vol. 42, no 3, pp. 293-338.

Etzkowitz H., Pique J. (2005) Silicon Valley in Transition from Network to Gravitation Field. Paper presented at the International Association Science Parks Conference, Helsinki, 2005.

Gokhberg L. (2003) Natsional'naya innovatsionnaya sistema Rossii v usloviyakh 'novoi ekonomiki' [Russia's national innovation system in the context of 'new economy']. Voprosy Ekonomiki, no 3, pp. 26-44 (in Russian).

Gokhberg L., Kouznetsova I. (2009) Innovatsii v rossiiskoi ekonomike: stagnatsiya v preddverii krizisa? [Innovation in the Russian Economy: Stagnation before Crisis?]. Foresight-Russia, vol. 3, no 2, pp. 28-46 (in Russian).

Gokhberg L., Kuznetsova T., Agamirzyan I., Belousov D., Kitova G., Kuznetsov E., Rudnik P., Roud V., Sagieva G., Simatchev Yu. (2013) Ot stimulirovaniya innovatsii k rostu na ikh osnove [From fostering innovation to innovationbased growth]. Strategiya - 2020: Novaya model rosta (Kniga 1). [Strategy - 2020: New Growth Model (Book 1)] (eds. V. Mau, Y. Kouzminov), Moscow: Publishing House 'Delo, pp. 92-127 (in Russian).

Golitchenko O. (2006) Natsional'naya innovatsionnaya sistema Rossii: sostoyanie i puti razvitiya [National Innovation System of Russia: State-of-Art and Development Trends], Moscow: Nauka (in Russian).

Hoffman D., Radojevich-Kelley N. (2012) Analysis of Accelerator Companies: An Exploratory Case Study of Their Programs, Processes, and Early Results. Small Business Institute, vol. 8, no 2, pp. 54-70.

HSE (2011) Rossiiskii innovatsionnyi indeks [Russian Innovation Index] (ed. L. Gokhberg), Moscow: HSE (in Russian).

Lewis D.A., Harper-Anderson E., Molnar L.A. (2011) Incubating Success. Incubation Best Practices That Lead to Successful New Ventures, Ann Arbor, MI: University of Michigan. Available at: http://www.nist.gov/ineap/upload/IncubatingSuccess-Report.pdf, accessed 20.04.2014.

Malek K., Maine E., McCarthy I. (2012) A benchmark analysis of Canadian clean technology commercialization accelerators. IEEE PICMET Proceedings, pp. 863-845.

Malek K., Maine E., McCarthy I. (2014) A typology of clean technology commercialization accelerators. Journal of Engineering and Technology Management, vol. 32, pp. 26-39.

Miller P., Bound K. (2011) The Startup Factories: The rise of accelerator programmes to support new technology ventures, London: NESTA.

Nelson R.R., Winter S.G. (1982) An Evolutionary Theory of Economic Change, London; Cambridge, MA: Cambridge University Press.

O'Connell B. (2011) Start X: Training ground for Stanford's best and brightest, London; Cambridge, MA: Kauffman Foundation. Available at: http://www.entrepreneurship.org/en/eMed/eMed-Blog/2011/October/StartX-Traininggroupnd-for-Stanfords-best-and-brightest.aspx, accessed 10.06.2012.

RVC (2014) Karta akseleratorov. Infografika [Map of Accelerators. Infographics]. Russian Venture Chronicle, no 1, pp. 24-25 (in Russian).

Timokhina E. (2014) Obitaemyi Lift, ili incubator na rynochnykh usloviyakh [Inhabited Lift, or marked-based incubator]. Delovaya Sreda, 06.02.2014. Available at: http://journal.dasreda.ru/practice/4852-obitaemyy-lift-iliinkubator-na-rynochnyh-usloviyah, accessed 09.12.2014 (in Russian).

World Bank, infoDev Finance (2012) Early Stage Innovation Financing (ESIF) Facility, Washington, D.C.: World Bank, infoDev Finance.

Yin R.K. (2003) Case Study Research Design and Methods, Thousand Oaks, CA: Sage. 